\title{
Caipira: cultura, resistência e enraizamento
}

IVAN VILELA ${ }^{I}$

M UITO SE comenta sobre o papel de cronista que a música popular adquiriu ao longo de sua existência. Entendemos por música popular brasileira a música que passou a ser produzida no universo urbano desde fins do século XIX e que foi valorizada e divulgada pelo disco.

Mas se olharmos para um tempo mais remoto, quando o Brasil era ainda colônia de Portugal, perceberemos que essa característica da música de ser cronista já existia e para tal podemos olhar para Gregório de Mattos Guerra, poeta e advogado que viveu na segunda metade do século XVII. Conhecido como Boca do Inferno, Gregório produziu uma expressiva parte de sua obra com versos setessílabos, coplas, ora ferinas, ora fesceninas, para relatar escândalos políticos e acontecimentos cotidianos de Salvador. Por mais de uma vez se escondeu no Recôncavo em fuga de ameaças de morte devido aos seus versos (Barros, 1999).

Esse papel narrador da música vem de longe. Diversos povos do mundo, quando iletrados, sobretudo, escolhiam alguém para ser o guardião da história de seu povo. Pessoas encarregadas de passar adiante a narrativa dos fatos vividos pelo grupo. Assim foram os veládicas na Índia, os moganis e metris árabes, os glee-men anglo-saxões, os bardos celtas, os aedos e os rapsodos gregos, os griots na África subsaariana e os cantadores no Brasil (Camara Cascudo, 1984).

Se imaginarmos que um nosso amigo nos contou agora uma história e tenhamos que a reproduzir imediatamente, conseguiremos contá-la com a maior fidelidade possível, porém, com nossas palavras. Entretanto, se aprendemos uma história que é ritmada, tal qual um poema ou ainda rimada e cantada, daqui muitos anos conseguiremos reproduzi-la com a total fidelidade que nos foi passada. Um artifício mnemônico para guardarmos o que aprendemos.

Durante todo o processo de colonização no Brasil reparamos que muitas dessas manifestações musicais surgiram a partir de encontros e sínteses do material aprendido com o já existente.

Quando Debret passou pelo Rio de Janeiro, no início do século XIX, reparou que negros se reuniam nas praças para tocar. Esses atuavam como barbeiros, aplicadores de sanguessugas e tiravam dentes, porém, nas horas vagas, tocavam, segundo Debret (1940, v.I, p.151), música europeia já muito antiga, mas davam a ela um outro caráter musical: “[...] tocavam valsas e contradanças francesas, em verdade arranjadas ao seu modo". Ora, esses músicos não estudaram estética, nem estilo, nem história da música europeia, e quando tocavam as partituras de 
música europeia tocavam a partir de seus próprios arcabouços culturais, criando assim uma música que tinha uma forte dose de autorreferenciamento, característica que reputamos às músicas populares do continente americano. Vale lembrar que o palco de encontro dos povos africanos foi o continente americano, posto ter sido o continente americano o principal local receptor de escravos provenientes da África. ${ }^{1}$

Por outro lado, observamos que grande parte do nosso saber foi construído de maneira oral. Se buscarmos as datas de fundação das primeiras universidades da América espanhola chegaremos no século XVI (Universidade Nacional de San Marco, no Peru, e Universidade Nacional Autônoma, do México, ambas de 1551) e no início do século XVII (Universidade Nacional de Córdoba, na Argentina, de 1613). Nossas primeiras universidades datam do século XX. ${ }^{2}$ Mesmo a imprensa se fixou no Brasil somente com a vinda da Família Real, em 1808.

Diante da ausência de instâncias de saber erudito no Brasil, percebemos que grande parte do nosso saber foi construído de maneira oral, o que gerou uma imensa diversidade no que se refere à nossa cultura popular.

El relato oral es móvil, lo que impide su esclerosamiento. A diferencia del libro no caduca: se transforma. Es un médio de transmisión de conocimientos que en mayor o menor grado vehicula una carga subjetiva, la que incluye los fermentos que permitieron al mito cambiar de máscara, responder a las nuevas situaciones. (Colombres, 1995, p.139)

Com o advento da República, que teve parte de seu ideário calcado na valorização da ciência e do saber erudito advindos do positivismo e também de um processo de racionalização industrial já presente no Brasil no início do século $\mathrm{XX}$, todo esse saber popular foi deliberadamente afastado das instâncias educacionais, administrativas e religiosas.

[...] o último quartel do século passado (XIX) marca o início da revolução que se iria operar, pois as campanhas abolicionistas e a urbanização paulatina das condições de existência iriam deitar por terra as relações patrimonialistas e a concepção tradicional do mundo correspondente [...] Então começa a desagregação da cultura popular. O "escravo" e o "homem do povo" desconheciam quase completamente os motivos e os padrões ideais que tornavam atitudes, técnicas e instituições tradicionais valores socialmente pouco conspícuos e desejáveis nas camadas dominantes. (Fernandes, 1979, p.31)

Durante os séculos XVIII e XIX, quando a nossa cultura popular estava sendo gestada e se configurava tal qual a conhecemos, nossa elite estava de costas para o Brasil tentando ser europeia e não presenciando esse processo sócio-histórico que gerou essa cultura e ainda hoje olha para ela e não a reconhece como sua.

Se voltarmos os olhos aos grandes compositores de música popular dos anos 1930 veremos que grande parte deles provinha de estratos sociais de bai- 
xa renda. No samba carioca (Cartola, Geraldo Pereira, Wilson Batista, Nelson Cavaquinho, Ataulfo Alves) e na música caipira, em São Paulo (Cornélio Pires, Zico Dias, Ferrinho, Raul Torres, Mineiro e Manduzinho, João Pacífico, e nos anos 1940 Tonico e Tinoco, Zé Carreiro e Carreirinho, Sulino e Marrueiro).

A música produzida por esses artistas atuou como cronista de todos esses povos que não tiveram uma outra maneira de contar a sua história.

\section{Mudanças}

No início do século XX, São Paulo mudava. Mudava em tamanho e mentalidade. Aspirava novos ares, o de ser cidade grande. A contraposição com o campo se tornava cada vez mais intensa. Em 1918, Monteiro Lobato escreveu Urupês, onde expôs sua percepção acerca da cultura caipira, tradicional, longe do progressismo advindo com os migrantes italianos. Notemos que a identificação de Lobato se dá não com o camponês, mas com a elite rural que ele representa como dono de terras. A elite rural se reconhecia próxima às camadas da elite urbana, mandando seus filhos estudar na Europa e inteirados das etiquetas e modismos dos salões da alta sociedade.

São Paulo mudava agora a passos largos. A maneira como o mundo da técnica e das invenções - que entravam gradativamente como facilidades cotidianas e de racionalização prática - ocupou a vida de todos parecia não ter volta. A proposta de um mundo limpo e civilizado, onde por vezes a forma prevalecia sobre o conteúdo, fizeram cada vez mais a cidade se tornar diferente do campo. ${ }^{3}$

A secularização e a racionalização dos modos de agir e pensar criaram confrontos entre o saber tradicional e o saber erudito. As pessoas de camadas mais populares viram-se cada vez mais envolvidas em situações que exigiam delas novas atitudes. Atitudes essas incompatíveis com os modelos tradicionais de comportamento (Fernandes, 1979).

A partir dessa época presenciamos uma valorização maior do saber erudito. A própria Igreja, a partir das romanizações e em consonância com as instituições dominantes, foi se tornando menos tolerante com as manifestações do catolicismo popular e as crendices que em torno desse transitavam.

As instituições oficiais passaram a exercer pressões mais drásticas contra os elementos culturais que pareciam perpetuar um "estado de ignorância e de incultura". No que toca às instituições educacionais imprimiu-se uma organização mais eficiente à difusão e à democratização decorrente do saber erudito. Este processo se fez acompanhar, às vezes, de tentativas deliberadas de degradação das manifestações do saber tradicional. (Fernandes, 1979, p.32)

Foi esse o cenário que Cornélio teve pela frente para divulgar a cultura caipira e seus atributos em São Paulo. As gravações realizadas por ele em 1929 e as que se sucederam acabaram por abrir um dos filões mais rentáveis da indústria fonográfica brasileira, o da chamada música caipira. 


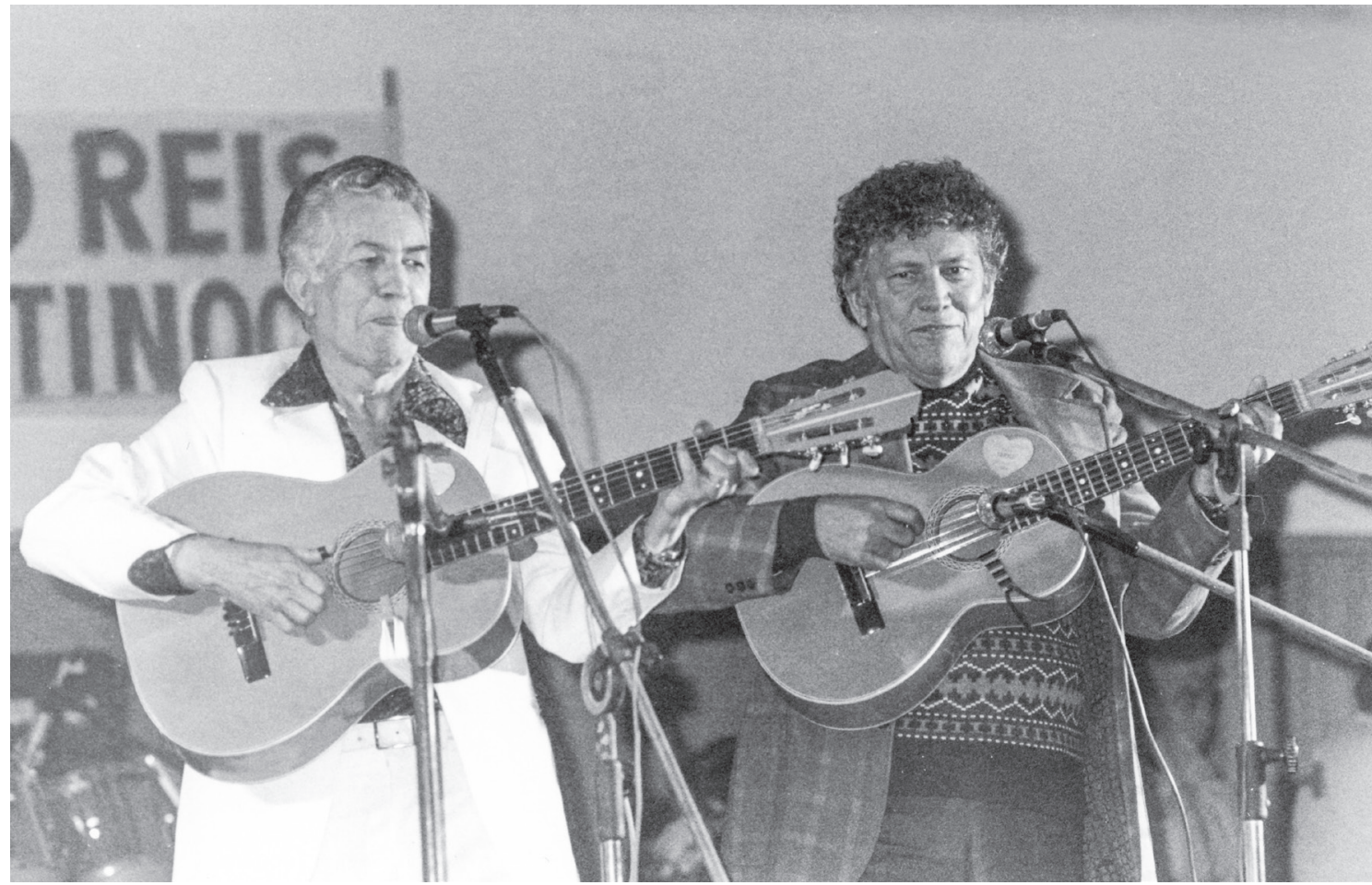

Show da dupla Tonico e Tinoco em São Paulo.

Foto Antonio Lúcio/Agêncai Estado - 4.9.1980

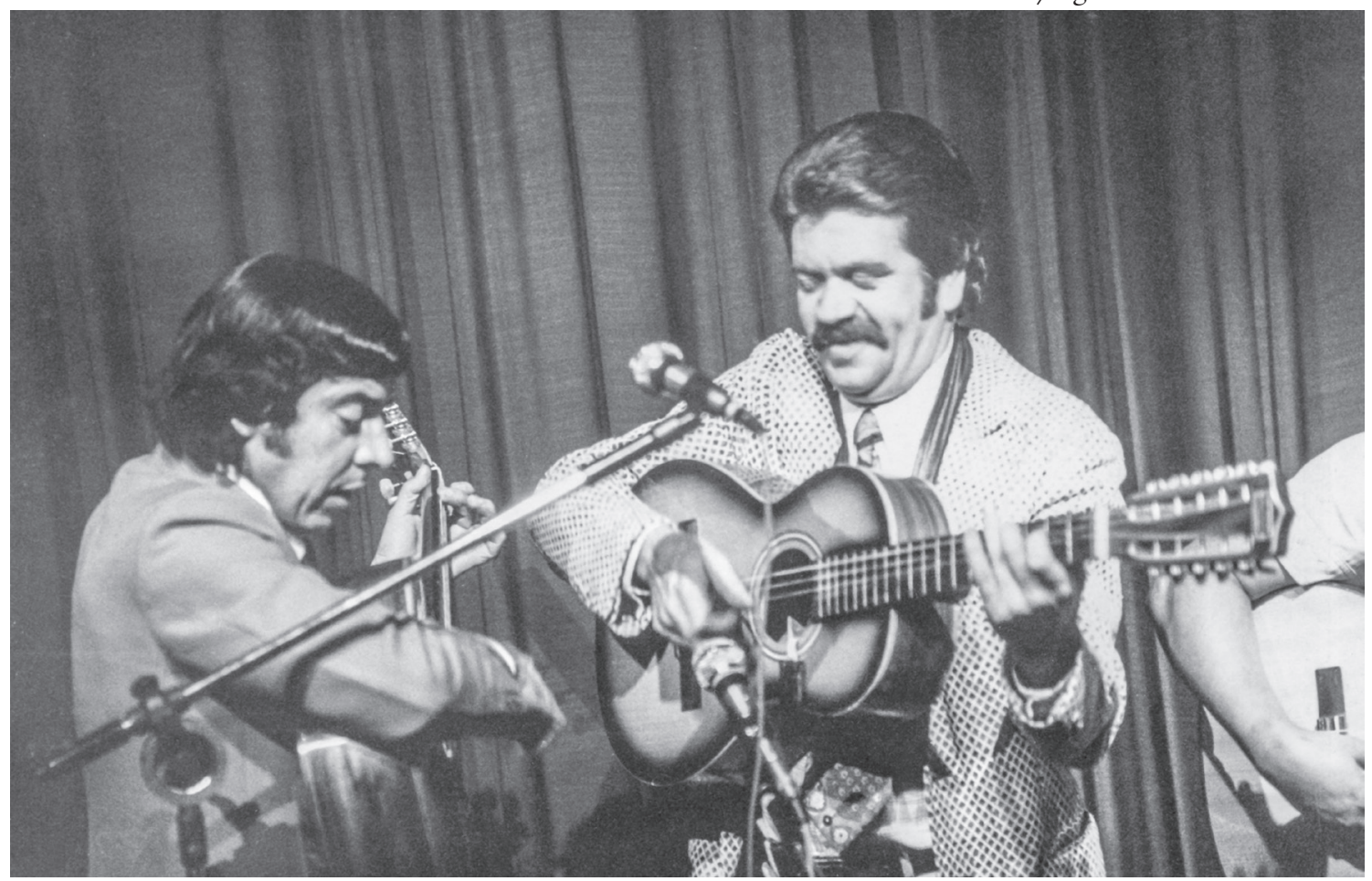

Show da dupla Mineiro e Manduzinho em São Paulo. 
Cornélio estava ciente desse panorama desfavorável à divulgação de uma cultura que agora era vista como atrasada ante a nova mentalidade que se instaurava em São Paulo e no Brasil. Por iniciativa própria, resolveu promover, em 1910, no Colégio Mackenzie, um final de semana com manifestações da cultura caipira que trouxera do interior. Vieram cantadores de cururu e dançadores de cateretê, ${ }^{4}$ apresentou ao público urbano o romance cantado, chamado por ele de moda de viola. ${ }^{5} \mathrm{O}$ sucesso de Cornélio foi notório, o que o fez começar a se apresentar, a partir de 1914 como contador de causos e a lotar teatros e cinemas reunindo pessoas de todos os estratos sociais.

É curioso que um colégio presbiteriano tenha aberto as suas portas a uma cultura que tinha o catolicismo popular como uma de suas principais expressões. O Vaticano, desde a década de 1830, vinha afastando as manifestações ligadas ao catolicismo popular das principais igrejas, como aponta Martha Abreu (1999, p.33).

O século XIX recebeu de herança o que ficou conhecido como "religiosidade colonial" ou "catolicismo barroco" [...] Em geral, dentro dessa prática religiosa, o clero secular tinha uma atuação que se limitava à celebração de alguns sacramentos (batismos, missas, comunhões, casamentos e extrema-unções) em datas específicas. Seu trabalho de evangelização sempre foi pouco expressivo, devido aos limitados recursos que a Coroa enviava, à sua deficiente formação religiosa e à grande dependência em relação aos leigos. As ordens religiosas, por sua vez, mais preparadas para disseminar um catolicismo dentro da ortodoxia religiosa, não conseguiam atingir todos os fiéis. Dessa forma, os leigos tornaram-se os maiores agentes do catolicismo barroco, repleto de sobrevivências pagãs, com seu politeísmo disfarçado, superstições e feitiços que atraíam muitos negros, facilitando sua adesão e paralela transformação.

Podemos observar claramente esses sincretismos nos ritos do Congado mineiro.

Muito incomodado com essas hibridações ocorridas no seio de sua doutrina, começa, o Vaticano a partir de concílios, a criar determinações de condutas e procedimentos, chamadas romanizações, a fim de restaurar, sobretudo na América Latina, o catolicismo canônico. Festas como a do Divino Espírito Santo no Rio de Janeiro, capital do Império, mobilizavam populações de diversas regiões e duravam dias. Com as romanizações, esses ritos foram migrando para as igrejas das periferias e daí para o campo, na medida em que o poder eclesiástico se estendia aos cantos da cidade.

O mesmo ocorreu em São Paulo com as mudanças de costumes advindos da crescente modernização da cidade e da falta de incentivo às manifestações do catolicismo popular por parte das instâncias religiosas, como nos mostra Vinci de Moraes:

Na capital, ainda no segundo quartel do século XIX aparecia a folia ruidosamente festiva com seus numerosos e barulhentos figurantes, mas a multidão 
com que a vida intensa de hoje abarrota as grandes cidades, comprimiu-a e sufocou-a nas antigas e soturnas ruas da Pauliceia, acabando por exterminá-la. (Afonso de Freitas apud Morais, 1997, p.102)

Uma pergunta nos surge: por que um colégio presbiteriano abriria as suas portas a manifestações de uma cultura que tinha suas bases religiosas ligadas ao catolicismo?

Desde o final do século XIX, começou a se estruturar o que entendemos por escola paulista de linguística nas pessoas dos presbiterianos, Julio Ribeiro, Otoniel Mota e Eduardo Carlos Pereira.

A partir deles desenvolveu-se uma linhagem de pesquisadores que compreenderam os ritos caipiras, bem como o seu dialeto, fora do marco da religião e da religiosidade. Como um repositório de uma língua autenticamente brasileira; ao que parece, essencial para o diálogo cultural e religioso com as populações sertanejas que era um território importante da ação missionária e do proselitismo protestante desde a segunda metade do século XIX. Para os protestantes, a roça era um território residual do catolicismo, área de hostilidade do catolicismo da romanização, como também no caso de Canudos e do Contestado. ${ }^{6}$

Talvez houvesse aí um interesse mais de cunho antropológico que religioso.

\section{A música caipira}

Cornélio, em 1929, bancou de seu próprio bolso a gravação de seis dis$\cos ^{7}$ de música caipira, os quais tinham uma numeração própria, diferente dos discos da Columbia, gravadora instalada em São Paulo. Tinham também uma cor diferente no selo e só poderiam ser vendidos pelo próprio Cornélio. O que foi previsto como um fracasso tornou-se um sucesso de vendas. Cornélio partiu de São Paulo rumo ao interior em fins de maio de 1929 com dois carros abarrotados de discos. A notícia de que havia um vendedor de discos com causos, anedotas e músicas cantadas pelos caipiras correu pelo telégrafo. Dois meses depois, quando chegou próximo a Jaú, distante pouco mais de $200 \mathrm{~km}$ da capital, Cornélio enviou um telegrama à fábrica pedindo nova prensagem, pois já havia vendido tudo (Ferrete, 1985).

Notamos aqui uma forte identidade cultural dos paulistas com essa música caipira que, embora nesse início produzida em grande parte por pessoas do meio rural, que se encontrava depreciado nas cidades, obteve uma forte aceitação no meio urbano. Notamos, em várias épocas, as tentativas dos processos civilizadores de aniquilarem com traços culturais nativos; porém esses nunca se mostraram muito eficazes como nos aponta Marshall Sahlins (1988, p.53) onde "os efeitos específicos das forças materiais globais dependem dos diversos modos como são mediados em esquemas culturais locais".

As primeiras gravações de música caipira, como foi citado, traziam uma sonoridade muito próxima ao campo visto serem seus protagonistas agricultores 
como Ferrinho, Manduzinho, Olegário e Mariano. Zico Dias, parceiro de Ferrinho, era motorista. No entanto, o mercado fonográfico da época, percebendo essa brecha de consumo aberta por Cornélio, investiu no segmento, mas sempre exigindo nas gravações um padrão de execução que não passava na ordem de preocupações de um camponês como tocar sem produzir ruídos e trastejados no instrumento.

Dessa forma, o mercado se abriu também a músicos urbanos, como foi o caso da chegada de Raul Torres, que mantinha um transporte na Estação da Luz e cantava emboladas nordestinas.

\section{A maneira de tocar do caipira}

A aparente falta de recursos para uma determinada ação pode impulsionar a criação de outros recursos que dificilmente seriam desenvolvidos. Com a mão enrijecida pelo trabalho no campo, o caipira descobriu recursos que dificilmente uma mão hábil em dedilhar se preocuparia em buscar. Falo de ritmos, de rítmica, de divisão. A maneira como um catireiro ou um pagodeiro ${ }^{8}$ conduz ritmicamente o acompanhamento de uma música é singular e sua execução com o balanço e sotaque esperados seria muito difícil de ser conseguida para uma autoridade no instrumento não iniciada nos meneios caipiras. A maneira "não limpa" de se tocar acaba por definir um novo padrão sonoro como ocorre na música flamenca, em que os violões são ajustados para terem as cordas rentes à escala para facilitar a execução de solos rápidos resultando disso o trastejar, que é o zumbir da corda no traste quando o instrumento é tocado com alguma força. Assim, o trastejado que é banido com todas as forças de uma execução erudita é um elemento de diversidade sonora na música flamenca e também na caipira.

O fato é que se exigia nas gravações um padrão de execução que conviesse aos já existentes, que eram limpos, sem ruídos.

Observamos ainda uma abertura desse novo segmento a manifestações sonoras diversas. Assim, nas gravações dos anos 1930 encontramos inúmeros instrumentos que não perduraram na música caipira nas décadas seguintes. $\mathrm{O}$ próprio instrumental do choro, que serviu de base para o samba no Rio de Janeiro, amparou algumas gravações de Raul Torres e Florêncio como em Do lado que o vento vai. Em Mestre carreiro escutamos triângulo, até então comum nas Folias de Reis do sudeste (hoje o triângulo nos traz uma alusão à música do nordeste, ao xote, ao baião). Na gravação de $A$ moda de mula preta escutamos um havaiano 9 com todas as suas distorções e portamentos.

\section{$\mathrm{O}$ rádio}

A primeira emissão radiofônica do Brasil, comemorativa dos cem anos da independência, foi feita em 1922. No entanto, as rádios começaram a operar efetivamente no ano seguinte. A primeira emissora de rádio de São Paulo foi a Educadora Paulista, inaugurada em 1923. No ano seguinte surgiu a Rádio Clube de São Paulo e, em 1927, a Rádio Cruzeiro do Sul. Foram muitas as rádios paulistas que mantiveram em suas emissões diárias programas de música caipira 
no amanhecer ou ao cair da tarde. Segundo Sant'Anna (2000), eram redatores dessas emissoras alguns poetas da Semana de Arte Moderna de 1922, como Menotti del Picchia e Guilherme de Almeida. Esses valorizaram em significativo espaço de programação a música dos caipiras.

Ora, os jovens que cresceram no interior e ouviam pelo rádio as músicas que diziam respeito à sua cultura, quando cresceram e foram cantá-la, trouxeram a ela o padrão sonoro mais próximo de suas realidades camponesas, como o som das Folias de Reis, das danças de São Gonçalo, das festas folclóricas. Partiram em duplas para as suas respectivas carreiras artísticas firmando no disco essa sonoridade mais ligada aos seus universos sonoros, ou seja, apenas o violão e a viola. Assim, nos anos 1940 despontaram Tonico e Tinoco, Zé Carreiro e Carreirinho e Sulino e Marrueiro.

Esse padrão fixou-se por décadas como o definidor da sonoridade caipira e embalou gerações dos anos 1940 até os anos 1960.

\section{Cronista}

Essa música, tendo como base poemática o romance, narrou fatos, contou histórias e transmitiu valores às populações de caipiras migrantes. A revolta de 1924, as revoluções de 1930, de 1932, a crise de abastecimento da gasolina na Segunda Guerra, a quebra da bolsa em 1929; todos esses fatos foram registrados em música.

Copiando o modelo estadunidense ocorrido décadas antes, a Marcha para o Oeste empreendida inicialmente por Getulio Vargas na busca da constitucionalidade da nação a partir da ocupação de todo o território nacional ficou registrada nas narrativas da música caipira, onde percebemos que a temática agrícola mudou-se para a pastoril. Músicas como Pingo d’água, de João Pacífico, deram lugar às narrativas de viajantes boiadeiros, como Boi soberano. A própria música Rei do gado aponta o ocaso do café ante a força da pecuária.

Esse avanço para o centro-oeste aproximou localmente as culturas paraguaia e brasileira, posto ser a pecuária na região do atual Mato Grosso do Sul uma fonte de trabalho para as populações fronteiriças.

Nessa aproximação, ritmos do Paraguai adentraram a música brasileira encontrando acolhida na música caipira. Ritmos como a guarânia e a polca paraguaia, também conhecida como rasqueado ou chamamé, passaram a compor a sonoridade e o interesse dos compositores e consumidores de música caipira no Brasil. Cascatinha e Inhana venderam, em 1952, dois milhões e meio de cópias ${ }^{10}$ da versão de Índia, feita por José Fortuna sobre música de José Assunción Flores e Manuel Ortiz Guerrero. Nos anos 1950, a bela voz do cantor mexicano Miguel Aceves Mejia trouxe também ritmos como a rancheira, o huapango e o corrido para o seio da música caipira.

Aqui uma curiosidade: nesta mesma época os Estados Unidos traziam ao Brasil, numa política de boa vizinhança, vários ritmos caribenhos já limpos etnicamente, ou seja, livres de seus instrumentos originais e tratados orquestralmen- 
te. Ritmos como o bolero, o chá chá chá, a rumba, o calipso e o mambo chegaram ao Brasil e foram acolhidos no seio da música popular produzida sobretudo no Rio de Janeiro que tinha o samba como carro-chefe. O bolero se aproximou do samba-canção resultando numa interessante fusão, dada a semelhança rítmica existente entre ambas.

O que notamos aqui são atrações étnicas e culturais. Os ritmos ibero-indígenas americanos foram absorvidos pela música ibero-indígena brasileira, a caipira; e os ritmos afro-americanos do Caribe foram acolhidos no seio da música afro-americana brasileira, o samba, dada a semelhança de suas rítmicas e construções musicais.

\section{Mudanças}

Os anos 1960 foram marcados por profundas transformações no cenário musical brasileiro. Como resposta a uma nova forma de capitalismo e modo de vida que se instaurou no pós-guerra pelo American Way of Life, movimentos como o existencialismo sartriano e a contracultura dos beats e depois dos hippies mexeram com as estruturas do mundo ocidental pela ação dos jovens e o mercado fonográfico respondeu a isso. O rock'n roll conquistava jovens em todos os espaços.

Uma vertente mais comportada e comercial desse rock chegou ao Brasil com amplo apoio da mídia e aqui recebeu o nome de jovem guarda. Um misto de música romântica jovem italiana com forte influência de The Beatles, essa música foi de e ao encontro à música caipira.

Os filhos dos migrantes nascidos na cidade viviam uma idiossincrasia forte em suas vidas: recebiam uma educação tradicional, caipira, em casa, e uma educação "moderna" na rua, no trabalho e na escola. O mercado fonográfico, percebendo essa brecha, investiu numa nova tendência que seria marcada pelos caubóis da cidade. Agora com temática urbana e mistura de ritmos tradicionais da música caipira com ritmos vindos dos Estados Unidos, como o country, a balada romântica e o próprio rock, as novas duplas sulcavam um novo caminho de sucesso totalmente diferente das searas de seus antecessores ainda presos no universo rural das boiadas e empreitas agrícolas. Léo Canhoto e Robertinho iniciaram essa nova vertente com a canção country Apartamento 37, que curiosamente ficava no quinto andar. Daí, parafraseando Roberto Carlos que descia a Rua Augusta a 120 por hora, Léo Canhoto e Robertinho narraram aventuras automobilísticas urbanas em suas músicas.

A partir daí começou uma outra vertente e as duas conviveram por um tempo. Uma que trazia em seu bojo o instrumental acústico, o arcabouço rítmico pertinente à cultura caipira ${ }^{11}$ e suas hibridações ocorridas nos anos 1940 1950, uma temática ainda voltada ao universo rural e o canto duetado o tempo todo; outra já com um instrumental eletrificado com guitarras, órgãos, bateria, temáticas urbanas, abolição dos ritmos tradicionais e incorporação da balada, do country e do rock, e o canto ora duetado, ora não, existindo em parte das vezes apenas no refrão. 
$\mathrm{Na}$ entrada dos anos 1980, uma mudança brutal ocorreu no seio das gravadoras no Brasil: os velhos e experientes diretores artísticos foram substituídos por managers, comerciantes que nada entendiam de música, mas entendiam de lucros. Os elencos das gravadoras foram reduzidos. O princípio neoliberal tomou conta da arte transformando-a em um produto de venda e nada mais.

Nessa fase houve um grande avanço de uma vertente musical que ficou conhecida como romântico sertanejo. Essa juntava a canção romântica estadunidense com o canto duetado. A dupla protagonista dessa mudança foi Chitãozinho e Xororó. A essa altura a música caipira ou sertaneja autêntica, como prefiro chamá-la, foi perdendo o seu mercado. Artistas como Tião Carreiro e Pardinho partiram para gravações românticas cantadas em duplas como as que já havia nos anos 1970 com boleros, orquestras, bateria e teclado. Ocorreu aí algo curioso: suas vozes vincadas de uma forte carga étnica não ornaram bem com esse novo instrumental polido, cercado de efeitos sonoros. E a música caipira foi a passos largos perdendo espaço.

\section{Uma retomada}

Foi só nos anos 1990 que vimos alternativas surgidas das matrizes musicais caipiras. Duplas como Pena Branca e Xavantinho, amparadas por artistas como Renato Teixeira, Milton Nascimento e Tavinho Moura, abriram um novo espaço de consumo musical com o resgate de canções brasileiras ligadas ao universo rural, mas não necessariamente caipiras. Emplacaram sucessos como Vaca Estrela e Boi Fubá, de Patativa do Assaré, Viola quebrada, de Mário de Andrade, e Peixinhos do mar, folclore norte-mineiro recolhido e adaptado por Tavinho Moura, além de canções como Cio da Terra, de Milton Nascimento e Chico Buarque. O público jovem que via com resistência e parcimônia as vertentes românticas da música sertaneja se abriu a essa nova sonoridade.

O nome sertanejo foi alojado à vertente romântica deixando órfão de nome a autêntica música sertaneja, que ganhou também o nome de modão ou música de raiz. Uma mistura confusa de termos desde então vem tentando definir nichos e espaços de venda e público.

\section{Migração, desenraizamento e reenraizamento}

As mudanças de mundo vividas por esses migrantes foram fortes. Sair de um mundo regido pelo fototropismo, pelas estações do ano e pelo conhecimento prático surgido da observação da natureza, dos animais e das plantas, para um mundo onde o conhecimento técnico advindo de fontes eruditas de leitura e escrita e o comando de seu corpo agora feito por uma máquina imperavam foi mudança drástica. Essas camadas de migrantes sendo submetidas a novos esquemas de vida, à sua maneira, encontraram meios de fazer permanecer os seus valores.

[...] nesse processar, na sociedade brasileira, há uma progressiva imposição dos meios eruditos, civilizados e urbanizados aos meios populares e rús- 
ticos, de modo a modificar-lhes a vida sociocultural, substituindo os seus valores e comprometendo-os em novas perspectivas de sociabilidade e cultura. Entretanto se há observado que apesar de todo esse processo impositivo, os grupos rústicos resistem e sua cultura encontra meios de permanecer. [...] Há um momento em que um dos grupos concede e acaba por aceitar fórmulas propostas pelo meio socioculturalmente mais poderoso. Mas, essa concessão implica o abandono total de seus valores culturais? Tudo está a indicar que não, e podemos admitir que ao lado de um empobrecimento daqueles valores, de um modo geral, ocorra um revigoramento deles quando, por acumulação, se adensam em torno de algumas práticas e alguns costumes que encontram possibilidades de permanência. E, condensados nalguma esfera do folclore, irradiando-se dali como formas de explicação e modelo de comportamento, reduzindo ao contexto tradicional as novidades eruditas, ou as coisas, conhecimentos e situações que, de um modo ou de outro, poderiam escapar ao domínio popular. (Xidieh, 1993, p.81-2)

Diante do processo de desenraizamento vivenciado pelos migrantes caipiras, a música caipira e sua radiodifusão (sempre narrando histórias pertinentes ao universo de origem desses migrantes e, por conseguinte, transmitindo seus valores) operaram como fatores aglutinantes e reenraizantes na vida do camponês caipira e dos moradores das cidades pequenas que foram viver nas metrópoles. Agora urbana, essa música agiu como mantenedora dos valores referenciais desse povo no momento e após o êxodo rural.

Diante da larga aceitação que teve a música caipira nas décadas de 1930 a 1960 por parte do público paulistano e de toda a região que compreende a antiga Paulistânia, ${ }^{12}$ os caipiras tornaram-se os únicos camponeses - e como camponeses numa ordem capitalista, alijados das benesses obtidas como frutos do progresso - que tiveram a sua história conhecida e ouvida por todos. Através da radiodifusão e do mercado fonográfico sua história foi por eles mesmos narrada.

Num mundo onde quase só se aprende a história dos vencedores, por meio da produção musical dos caipiras tivemos acesso a uma história dos vencidos, dos que se sujeitaram, mas não tombaram. A história vista de uma outra perspectiva, a dos pequenos.

Enquanto artistas desse segmento estavam à mercê dos produtores e das gravadoras e suas metas de lucro e a serviço de um capitalismo que desenraizava por concentrar e não distribuir a renda, paradoxalmente eles puderam contar sua história de enraizamento. A radiodifusão fortaleceu, no seio dos migrantes, a manutenção de valores que paulatinamente vinham sendo fragmentados pela conjuntura socioeconômica.

A partir da observação da poesia das músicas caipiras vamos entendendo o processo vivido por essas populações nos anos em que essa música, apesar da vinculação com o mercado, conseguiu expressar nas narrativas os seus anseios, angústias, pressentimentos e constatações de seu cotidiano. Na medida em que os costumes e valores foram mudando, as poesias, às vezes ingenuamente, narra- 
vam essas mudanças. Enfim, valores e acontecimentos cotidianos foram sempre registrados.

\section{Novos tempos}

Apesar de toda situação de desenraizamento causada pela monocultura agrícola no campo e - a partir da supressão das culturas locais em troca de uma cultura de consumo - pela monocultura na cidade, recentemente temos presenciado lampejos de um renascer das culturas e valores locais em várias partes do país e do mundo. Talvez como um efeito colateral à tentativa de uniformização pela via do consumo chamada globalização. Isso se reforça com o surgimento de um pensamento ecológico que preconiza, dentre outras coisas, a preservação das diversidades culturais. Também a desilusão com o "sonho da cidade grande" tem feito as pessoas, agora impossibilitadas de retornar às suas raízes geográficas de origem, buscarem valores que nortearam outrora a sua formação. A honestidade, a independência moral, a solidariedade, uma maneira menos cobiçosa de se olhar para o mundo, uma preocupação maior com o ser que com o ter. Alguns desses valores já registrados por Oliveira Viana como traços camponeses no Brasil.

A partir de final dos anos 1980, as telenovelas incorporaram em sua temáticas cenários, tramas e personagens do universo rural. Entre elas, presente como ator, surgiu Almir Sater ${ }^{13}$ cuja figura representava o oposto da depreciação construída na cidade sobre o caipira, sua cultura, bem como sobre os tocadores de viola. No ofício de professor de viola reparamos que o número de jovens aspirantes a tocadores desse instrumento aumentou expressivamente durante e após as telenovelas.

Atualmente a música caipira tem povoado novamente os aparelhos de som e os programas de televisão. Uma nova vertente de músicos tem utilizado a viola como um instrumento idiomático, porém universal. Segmentos como o da música clássica, da música popular instrumental, do rock, têm incorporado a viola em seus repertórios.

O surgimento de grupos de tocadores de viola, chamadas Orquestras de Violas, ultrapassa uma centena, só no estado de São Paulo (Dias, 2012). São jovens e velhos, pessoas dos mais variados segmentos culturais e sociais reunidos, sobretudo, no resgate de valores narrados nas poesias caipiras.

O caipira, outrora visto como atrasado, agora pode ser visto como aquele que resistiu a uma onda de desenraizamento que atinge hoje pobres e ricos, cultos e incultos, crianças e idosos. Se antes, Simone Weil achava que o excesso de dinheiro e as conquistas militares desenraizavam as populações, hoje reparamos que o consumo impensado faz o mesmo, atingindo pessoas de todos os segmentos sociais, culturais e econômicos presentes na sociedade.

Percebendo no caipira não o atraso, e sim a resistência cultural, notamos que pela via da cultura é possível que não nos esqueçamos de quem sempre fomos. 


\section{Notas}

l Benjamim Taubkin, músico brasileiro conhecedor da cultura latino-americana, nos chama a atenção para essa importante informação que coloca o continente americano como o grande palco de encontros de etnias e culturas tão diversas.

2 Nossa primeira Universidade enquanto um conjunto de saberes diversos que dialogavam entre si foi a USP, de 1934. As tentativas propostas pela Lei de Maximiliano, em Manaus, ou mesmo o agrupamento das faculdades de Direito, Medicina e Engenharia no Rio de Janeiro em 1920 só foram vistos como Universidade em 1937, quando a elas foram agregados outros cursos (<https://ufrj.br/historia >). O mesmo ocorreu no Paraná, onde a instalação em um mesmo prédio das faculdades de Medicina, Engenharia e Direito não obrigou a elas o diálogo esperado para se tornar uma Universidade. A USP, em 1934, juntou as escolas de Medicina, Engenharia e Direito existentes e as colocou sob o eixo de comando dos cursos das Ciências Sociais.

3 Vale lembrar que campo e cidade nos séculos XVIII e XIX eram instâncias próximas quando muitos que viviam no campo, passavam o descanso dominical nas cidades. Período em que essas eram habitadas.

4 Danças dos tupis aproveitadas por Anchieta no seu trabalho de catequese.

5 A moda de viola é uma modalidade musical em que o texto tem tanta importância que, quando se canta, não se toca, ficando a viola reservada aos intervalos estróficos. Segundo Sant'Anna (2000), a viola toca no tempo de o ouvinte assimilar um trecho da história e se preparar para ouvir o próximo. É importante ressaltar que até início dos anos 1950, o romance foi a base poemática de praticamente todas as canções caipiras. Fato rompido pelo advento do pagode caipira, que trouxe a palavra, o mote como orientadores do discurso poético.

6 Explicação que me foi dada pelo sociólogo José de Souza Martins.

7 A numeração dos discos partiu de 20.000 a 20.005, o que fez vários pesquisadores, como Ferreti, afirmarem que se tratava de cinco títulos. Israel Lopes afirma serem seis títulos. Como a tiragem foi de cinco mil cópias para cada disco, totalizaram-se trinta mil. Notemos que as tiragens na época não ultrapassavam dois mil discos por não haver no Brasil uma quantidade expressiva de gramofones.

$8 \mathrm{O}$ tocador de catira e de pagode caipira, respectivamente.

9 Instrumento de cordas dedilhadas tocado horizontalmente. Na mão que muda as notas utiliza-se um material de superfície dura (slide) para correr sobre as cordas resultando numa sonoridade cheia de glissandos e portamentos.

10 Narrado por Cascatinha em gravação que possuo dele e de Inhana cantando a música "Índia".

11 Pelas minhas pesquisas pude constatar que a música caipira é o maior guarda-chuva de ritmos existentes na musica popular brasileira. São dezessete ritmos diferentes convivendo e se entrelaçando, quais sejam: cururu, cateretê, polca paraguaia, guarânia, querumana, recortado, pagode caipira, rancheira, samba rural, batuque, cipó-preto, lundu, congado, folia, jaca, toada e samba rural.

12 Paulistânia, segundo Alfredo Ellis Jr. (1896-1974) que cunhou este termo e o utilizou em alguns de seus livros, seria todo o espaço ocupado inicialmente pela cultura caipira no avanço do bandeirismo paulista. Compreende hoje os estados de SP, GO, MS, o sul de MG e o Triângulo Mineiro, o Norte do PR, parte sul de TO e MT, que é onde se produz e se consome música caipira até os dias de hoje. 
13 Exímio tocador de viola e compositor de rara beleza física no meio musical.

Referência

ABREU, M. O império do divino. Rio de Janeiro: Nova Fronteira, 1999.

ALVES, A. Arabesco - da música árabe e da música portuguesa. Lisboa: Assirio \& Alvim, 1989.

AMARAL, A. O dialeto caipira. 3.ed. São Paulo: Hucitec, 1976a.

. Tradições populares. 2.ed. São Paulo: Hucitec, 1976b.

ANDRADE, J. de. Cocho matogrossense: um alaúde brasileiro. São Paulo: Editorial Livramento, 1981.

ANDRADE, M. de. Dicionário musical brasileiro. Belo Horizonte: Itatiaia, 1989.

ARAUjO, M. G. J. de. Resenha - Os parceiros do Rio Bonito. Campinas, 1997 (mimeo.)

BAKHTIN, M. A cultura popular na Idade Média e no renascimento. 6.ed. São Paulo; Brasília: Hucitec; UnB, 2008.

BARROS, H. Gregório de Mattos - Antologia. Porto Alegre: L\&PM Editores, 1999.

BOSI, A. Dialética da colonização. 4.ed. São Paulo: Cia. das Letras, 1992.

BOSI, E. Memória e sociedade. 12.ed. São Paulo: Cia. das Letras, 1995.

. (Org.) Simone weil - a condição operária e outros estudos sobre a opressão. 2.ed.

São Paulo: Paz e Terra, 1996.

. Cultura de massa e cultura popular. Petrópolis: Vozes, 2003.

BRUNO, E. da S. Equipamentos, usos e costumes da casa brasileira. São Paulo: Edusp, 2001. v.5.

BUENO, E. Capitães do Brasil. Rio de Janeiro: Objetiva, 2006.

CAMARA CASCUDO, L. da. Vaqueiros e cantadores. Belo Horizonte: Itatiaia; Edusp, 1984.

CANDIDO, A. Os parceiros do Rio Bonito. São Paulo: Livraria Duas Cidades, 1975.

COLOMBRES, A. Palabra y artifício: las literaturas "bárbaras”. In: PIZARRO, A. (Org.) América Latina: Palava, literatura e cultura. Campinas: Editora da Unicamp, 1995.

CUNHA, M. C. da. História dos indios no Brasil. 2.ed. São Paulo: Cia. das Letras, 1998.

DEBRET, J.-B. Viagem pitoresca e histórica ao Brasil. São Paulo: Livraria Martins, 1940.

DIAS, S. S. A. O processo de escolarização da viola caipira: novos violeiros (in)ventano modas e identidades. São Paulo: Humanitas; Fapesp, 2012.

FERNANDES, F. Folclore e mudança social na cidade de São Paulo. Petrópolis: Vozes, 1979.

FERRETE, J. L. Capitão furtado, Viola caipira ou sertaneja? Rio de Janeiro: Funarte, 1985.

HIGA, E. R. Para fazer chorar as pedras: o gênero musical guarânia no Brasil - décadas de 1940/50. 2013. Tese (Doutorado em Etnomusicologia) - Faculdade de Música, Universidade Estadual Paulista “Júlio de Mesquita Filho”. São Paulo, 2013. 
HOLANDA, S. B. de. Caminhos e fronteiras. 3.ed. São Paulo: Cia. das Letras, 2001.

LIMA, R. T. Moda de viola - poesia de circunstância. São Paulo: Departamento de Museus e Arquivos, 1997.

LOPES, I. Turma caipira Cornélio Pires. São Borja: Edição do Autor, 1999.

MAGALHÃES, C. de. O selvagem. 4.ed. São Paulo: Cia. Editora Nacional, 1940.

MARTINS, J. de S. Capitalismo e tradicionalismo. São Paulo: Livraria Pioneira Editora, 1975.

Sociabilidade do homem simples. São Paulo: Contexto, 2008.

MORAES, J. G. V. de. Sonoridades paulistanas. Rio de Janeiro: Funarte/Bienal, 1997.

PEREIRA DE QUEIROZ, M. I. O campesinato brasileiro. Petrópolis: Vozes, 1976.

PIMENTEL, S. V. O chão é o limite. Goiânia: Editora da UFG, 1997.

RIBEIRO, D. O povo brasileiro. 2.ed. São Paulo: Cia. das Letras, 2004.

SAHLINS, M. Cosmologias do capitalismo. In: XVI REUNIÃO DA ASSOCIAÇÃO

BRASIlEIRA DE ANTROPOLOGIA. Campinas. Anais..., Campinas: ABA, 1988.

SANT'ANNA, R. A moda é viola. São Paulo: Arte e Ciência, 2000.

SOLER, L. Origens árabes no folclore do sertão brasileiro. Florianópolis: Editora da UFSC, 1995.

TINHORÃO, J. R. História social da música popular brasileira. Lisboa: Editorial Caminho, 2004.

TOMAZ, J. Anchieta. Rio de Janeiro: Biblioteca do Exército Editora, 1981.

VASCONCELOS, D. de. História antiga das Minas Gerais. Rio de Janeiro: Imprensa Nacional, 1948a. v.1.

v.2.

. História antiga das Minas Gerais. Rio de Janeiro: Imprensa Nacional, 1948b.

VILELA, I. O caipira e a viola brasileira. In: PAIS, J. M. (Org.) Sonoridades luso-afro-brasileiras. Lisboa: Imprensa de Ciências Sociais da Universidade de Lisboa, 2004.

Edusp, 2013.

. Cantando a própria história - música caipira e enraizamento. São Paulo:

XIDIEH, O. E. Narrativas populares. Belo Horizonte: Itatiaia; Edusp, 1993.

ZAN, J. R. Da roça à Nashville. Revista Rua, Campinas, 1989.

RESUMO - O presente artigo trata do surgimento da música caipira como uma expressão da cultura popular brasileira e como essa música, desde o momento em que foi gravada em disco e divulgada pelo rádio, ajudou no processo de reenraizamento dos migrantes caipiras na Grande São Paulo.

PALAVRAS-CHAVE: Música caipira, Enraizamento, Radiodifusão, História social.

ABSTRACT - This article deals with the emergence of Brazilian country folk (caipira) music as an expression of the country's popular culture and how this music, from the 
moment it was recorded and broadcast on radio, helped in the process of re-rooting the country's migrants in the city of São Paulo.

KEYWORDS: Caipira music, Rooting, Broadcasting, Social history.

Ivan Vilela é professor do Departamento de Música da Escola de Artes e Comunicações da USP. É músico, compositor e pesquisador. @ - ivanvilela@usp.br

Recebido em 30.6.2017 e aceito em 17.7.2017.

${ }^{\text {I }}$ Departamento de Música, Escola de Comunicações e Artes, Universidade de São Paulo, São Paulo, São Paulo, Brasil. 